The dykes of the radial set preserve primary fine-grained margins and coarse-grained centres ard are undeformed. Some of the tangential dykes are completely undeformed, some have foliated contacts and undeformed centres while others have a well developed schistosity throughout. Isoclinally folded horizons of homogeneous amphibolite which may be of intrusive origin also occur. It thus seems clear that dykes of the tangential set belong to a number of different generations. Probably some were syntectonic in age.

Although study of thin sections has shown that most of the supracrustal rocks underwent amphibolite facies, followed by retrograde greenschist facies metamorphism, it is possible that in some parts of the belt the metamorphic grade never reached amphibolite facies. Work on this problem is in progress.

The kind assistance and hospitality of Kryolitselskabet Øresund A/S during the field work is gratefully acknowledged. Prof. P. E. Cloud Jr., Univ. of California, Santa Barbara, is also thanked for helicopter assistance at the end of the season.

\title{
References
}

Bridgwater, D. \& McGregor, V. R. M. 1974: Field work on the very early Precambrian rocks of the Isua area, southern West Greenland. Rapp. Grønlands geol. Unders. 65, 49-54. Keto, K. 1970: Isua, a major iron discovery in Greenland. Kryolitselskabet Øresund A/S, $13 \mathrm{pp}$.

Moorbath, S., O'Nions, R. K. \& Pankhurst, R. J. 1973: An early Archaean age for the Isua iron-formation. Nature phys Sci. 245, 138-139.

\section{Deformation of the Isua supracrustal belt, southern West Greenland}

\section{Patrick R. James}

A reconnaissance investigation of the deformation of the Isua supracrustal belt was carried out at the end of the field season. Helicopter transport was kindly provided by Prof. P. E. Cloud Jr. (Univ. of California, Santa Barbara) who was visiting the area to search for possible early life forms in the rocks of the Isua supracrustal belt.

The structures contained within the supracrustal rocks and surrounding gneisses can be described with reference to two major deformation episodes, here designated $D_{1}$ and $D_{2}$.

The first phase of deformation $D_{1}$ produced an intense $L S$ tectonic fabric $\left(S_{1}, L_{1}\right)$ in both the supracrustals and in some of the surrounding gneisses. This fabric most commonly parallels the original bedding in the sediments and the original layering in the gneissic rocks. The type of fabric varies, depending upon the lithology of the host rock, with a lineated slaty cleavage developing in the finer grained metasediments and metavolcanic rocks whilst the gneisses developed mylonitic foliation and fluxion banding 
structures. Other minor structures associated with the $D_{1}$ fabric include microboudinage of the laminations in the banded ironstones due to the differing ductilities of the quartz rich and magnetite rich horizons, and also the flattening and elongation of objects such as conglomerate pebbles and pyroclastic fragments.

The planar fabric predominantly dips steeply to the east and has a down dip, steep easterly plunging linear component. It mostly parallels the trend of the belt margins and, at the southern end by the shores of the lake Imarssuaq, the fabric is vertical with a steep easterly plunging lineation. Within the narrow south-eastern arm of the supracrustal belt, the main fabric parallels the belt margins and at the contact mylonitic banded gneiss and finely cleaved amphibolites occur. Away from the contacts, within the gneisses on either side of the supracrustals, the mylonitic fabric rapidly decreases in intensity over a few hundred metres and the dip and plunge of the planar and linear fabric elements are consistently shallow.

The second phase of deformation $D_{2}$ again affects all of the Isua rock types. The most important effects of $D_{2}$ are a series of large and small scale tight to isoclinal folds which deform the banding and the $D_{1}$ fabrics. The folds are nearly coaxial with the $D_{1}$ lineation, plunging steeply south-east and with axial planes which trend NNE-SSW and dip steeply south-east. In the east-west trending part of the belt, $Z$ shaped folds predominate, whilst in the south-west and north-east at the main Isua ironstone deposit, $M$ shaped folds occur together with $S$ and $Z$ folds. In the southeast, the margins of the belt can infrequently be seen to be folded by tight $D_{2}$ structures.

Other minor structures are associated with the effects of the $D_{2}$ folding on the $D_{1}$ fabric. These include refolded and mullion microboudins in the banded ironstone, and refolded flattened pyroclastic fragments. $D_{2}$ axial planar fabrics are rarely developed but the finite strain fabrics evolved due to the superimposition of the two strains include remarkable $L$ tectonic rodding structures which characteristically develop in the cores of the $D_{2}$ major and minor folds. The Isua ore body predominantly carries this linear fabric, and its tabular shape is considered to be due to its special structural location in the core of a major $D_{2}$ fold.

The tangential set of metadolerite dykes within gneisses is arcuate and subparallel to and also cutting the margin of the supracrustal belt. Within the supracrustals these dykes cut the $D_{1}$ fabric, but are frequently folded by the $D_{2}$ minor folds with the occasional development of an internal fabric. Conversely, the radial dyke swarm, which appears to be later than the tangential set, cuts all previous structures.

From the variations in orientation and symmetry of the $D_{1}$ fabric in both the supracrustal belt and the adjacent gneisses, it is considered that the $D_{1}$ movement pattern consisted of a simple shear deformation caused by the upward movement of the 'inner' gneisses (in the north) relative to the 'outer' gneisses (in the south). The margins of this vertical shear belt are now seen as the shallow dipping $L S$ tectonic fabrics within the gneisses. From measurements of deformed pyroclastic fragments an estimate of vertical displacement of approximately $7 \mathrm{~km}$ is suggested. It is considered that the lack of symmetrical arrangement and recognisable pattern of the stratigraphy is due to the intensity and asymmetry of this first major deformation.

From the style of the minor $D_{2}$ structures, and the form of the Isua belt, it is con- 
sidered that its arcuate shape can be best explained as a major $D_{2}$ neutral fold with one hinge in the Imarssuaq lake and another just under the margin of the Inland Ice and probably containing the Isua ore body. The major folds are calculated as plunging steeply $\mathrm{E}$ to SE with steep easterly dipping and NNE-SSW trending axial planes.

The tangential dykes appear to have been intruded during a late stage of the $D_{2}$ episode, whilst the radial set are thought to belong to a later tensile phase. Finally, semi-ductile shearing and brittle truncation of the western arm left the supracrustal belt in its present form.

Dept. of Earth Sicences, University of Leeds, Leeds LS2 9JT, U.K.

\section{Field mapping of Bjørneøen and the adjacent coast of Nordlandet, Godthåbsfjord, southern West Greenland}

\section{Patrick R. James}

Mapping at a scale of 1:50000 was carried out on the gneisses and supracrustals of Bjørneøen and the granulites of the adjacent east coast of Nordlandet; the area has previously been described by Noe-Nygaard \& Ramberg (1961) and Bridgwater \& McGregor (1974). During the present study special emphasis was placed on the structural relationships of the various rock units and also on the relationship and contact between the amphibolite facies and granulite facies areas. A short excursion was made at the beginning of the field season around Godthabsfjord and Ameralik with the helpful guidance of V. R. McGregor whose kind assistance is especially acknowledged.

\section{Malene supracrustals}

Supracrustals of mainly basic and ultrabasic, volcanic and intrusive origin, and occasional minor sedimentary units, form a large part of both the Bjørneøen and eastern Nordlandet sequences. On Bjørneøen there is a major supracrustal pile which reaches nearly $1 \mathrm{~km}$ in thickness at its maximum on the south Bjørneøen coast. In various forms this pile caps most of the major $1000^{+} \mathrm{m}$ peaks of the island. Other supracrustals on Bjørneøen and on the coast of Nordlandet occur in bands up to $100 \mathrm{~m}$ in width and also minor pods and lenses enclosed in gneisses.

The ultrabasic rocks and related talc schists usually stand out due to their relative greater competence and resistance to erosion. A locality of pillowed ultrabasic was discovered on the plateau east of Qârusûp qáqâ. The basic supracrustal igneous rocks consist of banded, green and black, massive and pillowed amphibolites, fine grained, black amphibolites, occasional green, garnet rich diopside bands and lenses, and frequent large sheets and horizons of instrusive coarse metagabbro (leopard rock). Paler, intermediate igneous rocks are also interbanded with the basics and occasionally 